\title{
Danseterapeutiske spor \\ - fra rituel dans til globale netværk og postmoderne udfordringer
}

\author{
Af Helle Winther
}

»Han er lys og muskuløs og virker uscedvanlig høj. Han falder lidt sammen i den ellers så ranke ryg og der er nu, hvor han bare løfter hovedet og ser op, noget drenget og samtidigt opgivende over ham. Jeg har mistet min gnist, siger han. Jeg er så trcet. Jeg kan snart ikke holde mig selv oppe laengere. Jeg er bange for at gå helt ned.

Efter en stund er han i bevagelse. Ned $i$ kroppen, ned $i$ trcetheden. Hans bevagelser er tunge og ludende. Armene hoenger, ikke leddeløse, men afvoebnede som hos en bjørn, der ikke kender sin egen kraft.

Så begynder fodderne at tage mere fat $i$ gulvet. Benenes bevcegelser bliver stcerkere. Hofterne bevager sig fra side til side. Han lader søgende armene bevage sig $i$ et kraftigt trcek omkring kroppen, som om de på en gang skaber plads og skubber vaek. Det er alt det, der sidder $i$ min ryg. Alt det, jeg skal og skal for at vare så rigtig og have styr på det hele, ncesten råber han, mens han begynder at sla med fremadrettede boksende slag.

Hele hans krop er varm og kcempende. $\mathrm{Nu}$ er det tydeligt, hvor stor og umådeligt stcerk han er. Aggressionen fylder hans krop endnu en stund, indtil hans bevcegelser snarere udtrykker kraft end vrede. Så stilner det af. Hans hoender krydses foran brystet og finder så hinanden. Han grceder. En granvoksen mand, en professionel leder og en lille dreng, som selv er far. Til sidst siler tårerne bare af sig selv, mens han langsomt rakker hoenderne frem. Så begynder en dans, der bevager sig inde fra rygsøjlen og videre ud $i$ kroppen. Et øjeblik synes hans ryg at boere sig selv med en lethed som hos et helt lille barn. Let, uden stivhed og skrammer. En ryg, der synes loftet af en selvfølgelig lyst til livet, som kun den, der bevaeger sig med uforbeholden tillid kan have."

(Koncentrat af scenisk beskrivelse om 'Michaels' danseterapeutiske proces, Dansergia)

\section{Introduktion}

Mens danse- og bevægelsesterapi i Danmark er et relativt nyt og i mange sammenhænge ukendt og usynligt område, arbejder danseterapeuter på City Psychiatric Hospital i St. Petersburg i skrivende stund gennem krop, bevægelse og rytme med alvorligt syge patienter. På mange psykiatriske hospitaler i England, Tyskland, Sverige og USA er danse- og bevægelsesterapeuter en fast del af personaleteamet, ligesom de arbejder med autistiske børn, traumeramte, demente ældre, fibromyalgi-patienter og flygtninge (Koch \& Bräuninger, 2006; Koch 
\& Panhofer, 2007; Levy, 1988). I Danmark arbejdes der for øjeblikket primært med danse- og bevægelsesterapi som en vej til personlig udvikling.

Kroppens sprog kan nå mennesker i livssituationer, hvor ordene ikke slår til. Ordene søger ofte at forklare hvorfor og tale om. De kan nemt stikke af til det mentale. Den bevægelsesmæssige undersøgelse kan skabe modvægt til nutidens omsiggribende fokus på italesættelse. Den giver mulighed for også at undersøge løsningsmuligheder gennem en direkte oplevelse med kroppens grundlæggende ekspressivitet.

På trods af at kroppen er næsten fraværende inden for nogle grene af psykologien, er der i dag fra flere teoretiske vinklers side enighed om, at krop og psyke må ses som et sammenhængende dynamisk og organisk system med iboende kulturelle og samfundsmæssige betydninger, som kan aflæses direkte i det enkelte menneskes krop og bevægelse (Boadella, 2006; Csordas, 1999; Køppe, 2004; Merleau-Ponty; 1962/2004). Spørgsmålet er derfor, om der eksisterer et stadig uudnyttet potentiale $\mathrm{i}$ at inddrage krop og bevægelse i terapeutiske sammenhænge i forhold til både almen personlig udvikling og psykiatriske behandlinger? Dette spørgsmål er først nu for alvor begyndt at komme op til overfladen i Danmark. ${ }^{1}$ Artiklen tager afsæt i dette spørgsmål og afdækker spor af, hvordan de primært i udlandet fremherskende danse- og bevægelsesterapier - med rødder i danseritualer, den tidlige moderne dans og forskellige psykologiske teorier - også i praksis begyndte at arbejde med sammenhængen mellem krop, psyke og samfund, længe før den aktuelle interesse ekspanderede. To af danseterapiens pionerer portrætteres, og den nuværende internationale uddannelsessituation nævnes. Derefter kastes blikket på danseterapiformen Dansergia, ${ }^{2}$ der kortfattet præsenteres, analyseres og spejles i forhold til det øvrige danse- og bevægelsesterapeutiske felt. Afslutningsvis skitseres de hastigt udviklende europæiske tiltag og de postmoderne forskningsmæssige tendenser inden for feltet.

\section{Kroppens sprog og bevagelsens psykologi}

Udgangspunktet er et aktuelt forskningsprojekt med titlen Bevcegelsespsykologi om kroppens sprog og bevaegelsens psykologi med udgangspunkt $i$ danseterapiformen Dansergia (Winther, 2006). Projektet udforsker kroppens og bevægelsens personlighedsudviklende potentialer på baggrund af narrative metoder (Merleau-Ponty, 1962/2004; Sparkes, 2002). Denne artikel er primært historisk orienteret, og afdækningen af danseterapiens rødder danner på trods af en komprimeret og nøje udvalgt stofmængde et spor, der gennem nedslag i forskellige tidsperioder skitserer, hvordan udviklingen har formet sig. Skitsen fremtræder gennem fortællinger om markante personligheder og betydningsfulde tendenser. Hvor det er muligt, benyttes primære skriftsproglige kilder, men på grund af det tværgående overordnede fokus benyttes også oversigtslitteratur. Da formålet med artiklen er at vise aspekter af en større sammenhæng over en lang tidsperiode, vil det naturligvis ske på bekostning af en mere nuanceret beskrivelse af de enkeltstående tilfælde. $^{3}$ 


\section{Rituel dans - de tidligste spor af krop, dans og terapi}

Danseterapi, som er den psykoterapeutiske brug af bevægelse og dans, ${ }^{4}$ kan primært spores tilbage til begyndelsen af 1900-tallet parallelt med udviklingen af forskellige psykologiske retninger, og dog rækker de danseterapeutiske rødder meget længere tilbage (Grønlund, 1999; Halprin, 2003). Dans er på trods af en altid nærværende kulturel tone også et universelt livsudtryk, som går på tværs af kultur og tid, for dans har ligesom kamp og leg en prækulturel essens (Huizinga, 1993). Arbejdet med bevægelse og især dans som en form for katarsis, ritual eller tidlig form for psykoterapi er derfor måske lige så gammel som dansen selv (Levy, 1988).

De ældste former for dans var ofte rituelle danse, som i den nordiske kultur kan ses afbilledet $\mathrm{i}$ helleristninger og i nutiden spores gennem brudevalsen. Rituelle danse var kendetegnede ved at være forbundet med myter, særlige livsbegivenheder eller kriser, hvor helheden, fællesskabet og det universelle som oftest gik forud for individualiteten og den enkeltes historie. Gennem myten skabtes det almene, og gennem dansen fik myterne kropslig og erkendelsesmæssig betydning og følelsesmæssig forløsning. Man dansede for jagtudbytte, frugtbarhed, grøde og regn. Man dansede liv og død, krig og fred, sorg og glæde. Dans, musik, medicin og religion var uadskillelige fænomener (Grønlund, 1999; Merloo, 1960). Også i dag har nogle afrikanske, cubanske og brasilianske danse ligesom inuitternes danse rødder i rituel praksis. På trods af disse nutidige aktiviteter svandt de rituelle danse dog ind i takt med kristendommens indtog og den vestlige kulturs udvikling (Halprin, 2003). Dansen

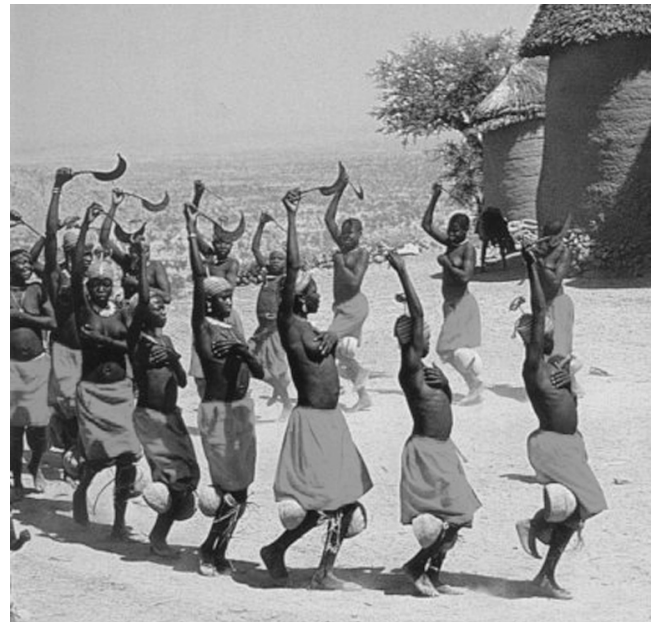

Masaikvinder. Ritueldans.

og specielt scenedansen i Europa udviklede sig væk fra det eksistentielle og - bortset fra de folkelige fællesskabende danse - hen mod en underholdnings- og repræsentationsfunktion, hvor kroppen blev disciplineret og dansens trin, især balletten, blev formaliseret ind i et victoriansk menneskeog kropssyn (ibid.). Det var dette bagvedliggende dualistiske kropssyn, der fremhævede det lyse, disciplinerede og åndelige på bekostning af kroppens sanselighed, som den gryende moderne dans i Tyskland og USA var et oprør imod.

\section{Moderne dans - den}

frigørende, naturlige og revolutionerende bevagelse

»Man behøver ingen let krop, ingen sarte bøjede fødder, ingen smidige rygbøjninger $i$ den moderne dans. Der er ingen traditionslaenker, ingen isnende konventioner, ingen forudfattede ideer. I stedet for at danse et skema andre har loert os, danser vi igennem dansens rige med vores egen krop. Bevagelse er magi.« (citat 
af Mary Wigman i Sorell, 1986 p. 46; her i oversættelse fra Winther, 1994 pp. 5354).

Den moderne dans blev opfattet som avantgarde og var forbundet med en emancipatorisk strømning i politik, kunst, litteratur, videnskab og samfund (Sorell, 1986; Trautmann-Voigt, 2006; Manning, 1993). Strømningen handlede også kropsligt set om at 'frigøre' mennesket og lade det udfolde sit fulde potentiale, hvilket også belyses i citatet af Mary Wigman (1886-1973). Hun var en af de første moderne danserinder og elev af og kollega til den store bevægelseskunstner, pædagog og bevægelsesfilosof Rudolf Laban (1879-1958) (Wigman, 1967; Sorell, 1986). Mary Wigman udviklede primært før anden verdenskrig med inspiration fra og som reaktion mod Laban sin 'Ausdruckstanz'. Gennem sin kunst udtrykte hun det, hun oplevede som både personlige og universelle følelser. Mary Wigman oplevede en ukendt frihed i dansen (Wigman, 1967). Hun opfattede som mange andre den moderne dans som en forløsning fra kulturens og civilisationens lænker og virkede med sine dæmoniske hekse- og dødedanse, og især i kraft af sit køn, utroligt provokerende for sin samtid (ibid.; Sorell, 1986; Manning, 1993).

Den moderne dans lod sig inspirere af rituel dans, græsk teater og de nye psykologiske teorier. Den udviklede sig nemlig i samme periode som Sigmund Freuds (18561939), Gustav Jungs (1875-1961) og Wilhelm Reichs (1897-1957) arbejder, og dette forhold fik stor indflydelse på både den moderne dans' arbejdsmetoder og indhold (Levy, 1988). Nøgleordene i den moderne dans var spontanitet, autenticitet og ekspressivitet, og der blev søgt efter nye former for kreative bevægelsesudtryk, som ikke bare udtrykte dansernes egne personlige oplevelser og indre følelsesmæssige indhold, men også almenmenneskelige temaer (Manning, 1993).

De tre store danserinder, som især fik indflydelse på det senere danseterapeutiske arbejde, var udover Mary Wigman amerikanerne Isadora Duncan (1878-1927) og Martha Graham (1894-1991) (Wigman, 1967; Duncan, 1927; Graham, 1991). Isadora Duncan var danser, samfundskritiker, storbyboheme, naturelsker og poet. Med udslået hår, bare fødder, en blødhed i torso og en kontakt til 'solar plexus' dansede hun dionysiske danse i naturen, mens hun søgte ind til kroppens spiritualitet og den naturlige bevægelses udspring i modsætning til det, hun opfattede som det civiliserede menneskes unaturlige bevægelser (Duncan, 1927). I udforskningen af bevægelsens 'crater of motor power' var Isadora Duncan optaget af bølgernes bevægelse $\mathrm{i}$ havet, i lyset, i lyden og også stilheden i hendes egen krop (ibid.).

Hvor Isadora Duncan arbejdede med den naturlige bevægelse, skulle fokuseringen på kroppens center, tyngdepunktet i midten af kroppen, sammen med princippet »Emotion is motion «, blive Martha Grahams primære indflydelse på danseterapien. Hun oplevede kroppen som et udtryk for alle livets grundelementer og som en bevægende hukommelse for alt, hvad der angår livet, døden og kærligheden (Graham, 1991). Martha Graham havde nemlig ligesom Wigman og Duncan en intens kunstnerisk interesse for sammenhængen mellem følelsernes og de psykologiske temaers udtryk i den menneskelige krop, hvilket uden tvivl var forbundet med den omsiggribende psykoanalytisk inspirerede tendens i samtiden og det fælles budskab i den moderne dans (Levy, 1988). Hvor der i balletten primært arbejdedes med 


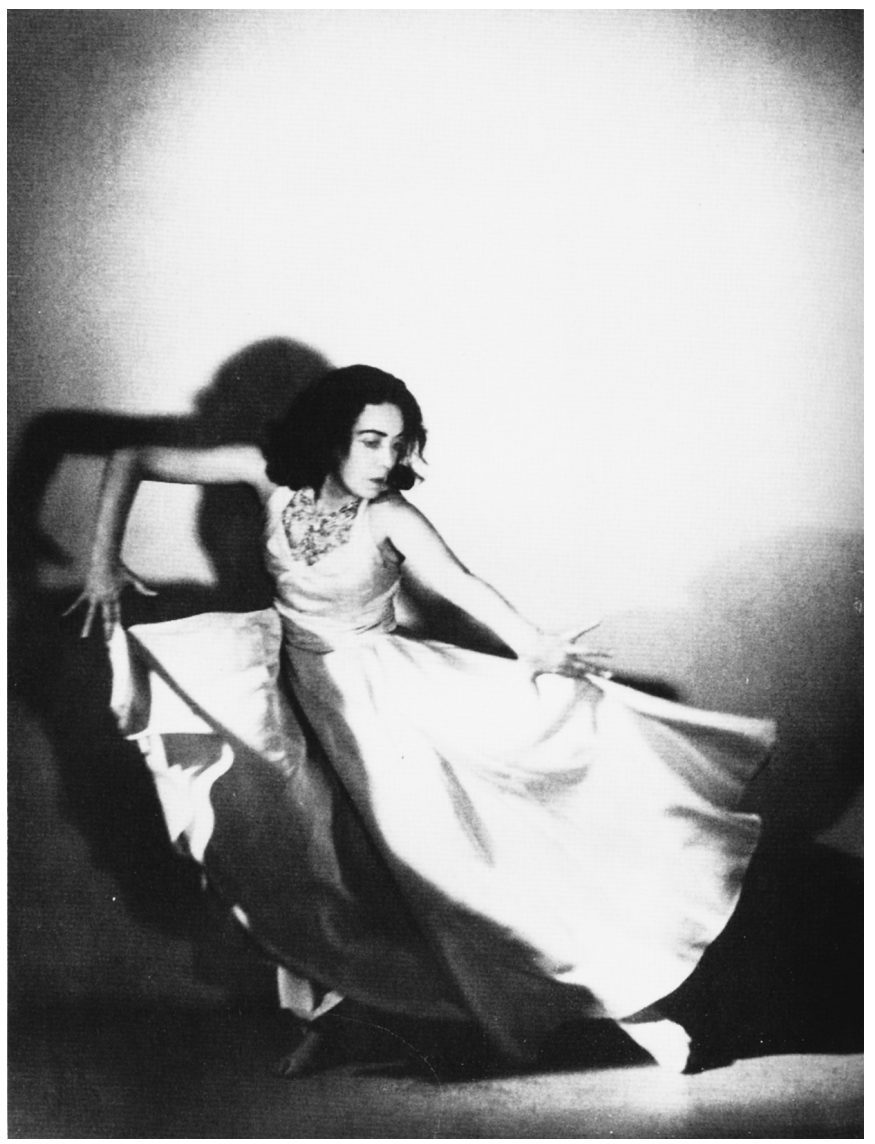

Mary Wigman, 1937.

Herbstliche Tänze Winds-

braut.

det lyse og luftige udtryk, undersøgte man i den moderne dans altså også de dunkle sider af menneskets sjæleliv. Mens de rituelle danse udsprang af en helhedsforståelse af krop, psyke, spiritualitet, kunst og samfund, udfordrede de moderne dansere med deres ideologiske holdninger det 19. århundredes autoritetsbaserede magtstrukturer, manifesteret i kirken, staten og videnskaben ved at søge en i både fysisk og psykisk henseende udtryksfuld krop frigjort fra den kulturelle spændetrøje (Sorell, 1986; Wigman, 1967).

Det kunstneriske arbejde blev derfor for mange moderne dansere følelsesmæssigt intenst og udfordrende. Stort set alle de store pionerer inden for danseterapien begyndte deres karriere som moderne dansere. Det var gennem intense oplevelser som performere og undervisere, at de erkendte de store potentialer $\mathrm{i}$ at bruge dans og bevægelse som en form for psykoterapi (Whitehouse, 1969).

Danseterapien, pionererne og samspillet med forskellige psykologiske retninger

"As one watches these patients - very sick psychotic patients - and Miss Chace dancing, one gains the impression that through this medium the patients have at least found it possible to step out of their constricted world and quoting one of 


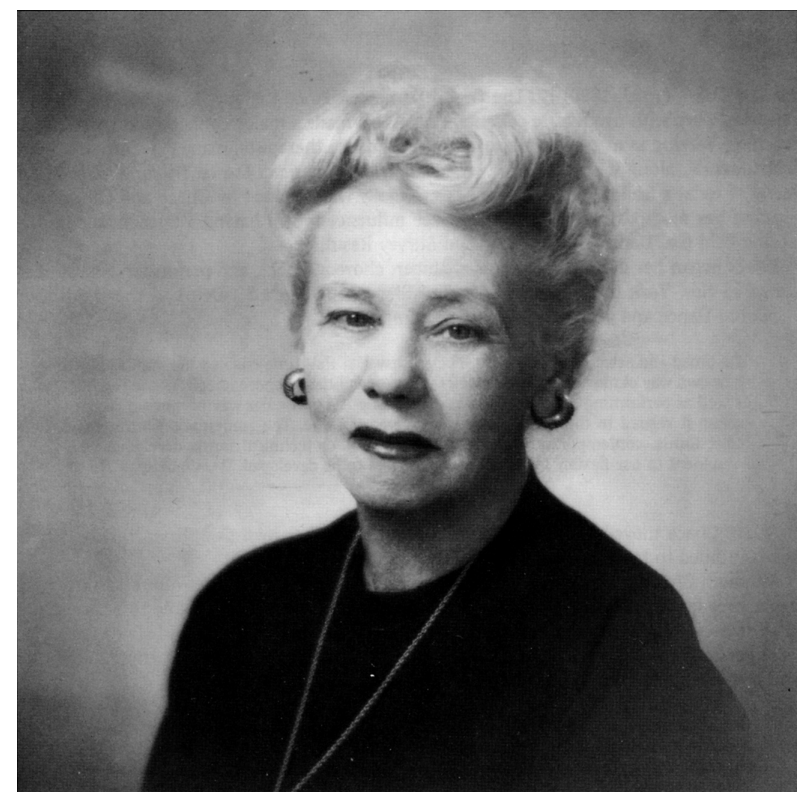

Marian Chase. Danseterapiens 'Grand Dame'.

them: "to reach outward." Their movements seem free, easy, comfortable; they undulate, flow and appear to express in motion and rhythm what they cannot express in words or in conventional social actions. That they can do this is a tribute to the unusual qualities of Miss Chase as a Dance therapist but it is also a reminder to us that there are few if any sinaccessible» patients« (Dr. Jay Hoffman i Chaiklin, 1975, pp. 81; her fra Levy, 1988, pp. 23).

Psykiateren Dr. Jay Hoffman understregede i 1940'erne potentialet $i$ at arbejde med danseterapi, endnu før man egentlig kendte denne faglige benævnelse.

De grundlæggende danseterapeutiske spor siges i de fleste sammenhænge at være sat af seks kvinder fra USA's øst- og vestkyst, de seks pionerer, som alle havde en baggrund i den moderne dans, og de udvik- lede et bredt fundament af kliniske metoder, som kan spores i danse- og bevægelsesterapien den dag i dag (Levy, 1988; Trautmann-Voigt, 2006). ${ }^{5}$

Det følgende fokuserer især på to af pionererne: Marian Chase (1896-1970), danseterapiens »Grand Dame« og Mary Whitehouse (1911-1979), som er den, der har skrevet mest om sit arbejde. ${ }^{6}$ I 1940 'erne begyndte den tidligere danser og koreograf Marian Chase $^{7}$ at eksperimentere med dans og terapi. Hun startede som frivillig på Saint Elizabeths, det største statslige psykiatriske hospital i Washington DC-området, og arbejdede med dans og terapi i psykiatrien i næsten 25 år (Chaiklin, 1975; Levy, 1988; Trautmann-Voigt, 2006). Marian Chase var overbevist om, at enhver patient havde en længsel efter at kommunikere og udtrykke sig, også selv om denne længsel umiddelbart syntes at være begravet (Levy, 1988). Chase fokuserede på ressourcerne $\mathrm{i}$ 
det non-verbale sprog og søgte altid efter de områder i patienternes personlighed, som stadig var kontaktbare og tilgængelige.

Hun havde et skarpt blik for, hvordan de psykiske sygdommes patologi også skabte split i både kropsbilledet og patienternes kontakt til egen krop. Hun søgte efter selv de mindste tegn på, at patienterne gennem deres kropslige fremtoning fortalte, at noget ville ses og høres, og kunne forstå den skizofrenes forvirrede verden ved at spejle den i sin egen krop (Chaiklin, 1975; Grønlund, 1996). For de psykiatriske patienter blev Marian Chase i 1940'erne repræsentant for de sunde vækstressourcer i mennesket (Trautman-Voigt, 2006). Selv om hun aldrig selv nævnte inspirationen fra den samtidige Wilhelm Reich, arbejdede hun parallelt med ham med nogle af de samme ideer om det kropslige arbejde som en vej til at åbne for følelser og oplevelser, der lå gemt i åndedrætsrytmen, koordinationsmønstrene og muskulaturen, og hun mente også, at psykiske og emotionelle blokeringer kunne ses af et trænet øje (Chaiklin, 1975; TrautmanVoigt, 2006).

Mary Whitehouse, en af vestkystens fremtrædende pionerer, var stærkt inspireret af dels Mary Wigman, som hun havde danset hos i Dresden før anden verdenskrig, og dels af jungiansk psykoanalyse (Levy, 1988; Grønlund, 1996; Whitehouse, 1979). Mary Whitehouse opdagede langsomt bevægelsens multidimensionalitet.

»Gradually I came to see that movement is one of the great laws of life. It is the primary medium of our aliveness, the flow of energy going on in us like a river all the time, awake or asleep, twenty-four hours a day. Our movement is our behavior; there is a direct connection between what we are like and how we move. Dis- tortion, tension, and deadness in our movement is distortion, tension, and deadness in ourselves « (Whitehouse, 1969, p. 63).

Mary Whitehouse, som udviklede det, hun kaldte autentisk bevægelse, arbejdede videre med et af Wigmans principper, som handlede om at lade bevægelserne komme af sig selv. Forskellen på at gøre bevægelsen og lade det ske var en stor udfordring for mange, især trænede dansere, fordi det handlede om at finde nærværet $\mathrm{i}$ » not - moving« (Chodorow, 1991; Whitehouse, 1979). Det kunne være konfronterende at skulle vente på en »indre« bevægelsesimpuls (Chodorow, 1991). Netop det øjeblik, hvor noget begynder at ske, hvor det ikke handler om at bevæge sig, men iflg. Whitehouse om »at blive bevaget«, er en overgivelsesproces, hvor ego'et for en stund - måske som i elskov - sættes ud af spil:

"It is the moment where the ego gives up the control, stops choosing, stops exerting demands (...) it is a moment of total surrender that cannot be explained, repeated exactly sought for or tried out. This is humbling and freeing for the personality that demands perfection, control, conformity - all the ills of our social training«(Whitehouse, 1979, pp. 79; Houmark, 1994, pp. 76).

\section{Fra pionerer til verdensomspcendende rodnet}

Pionererne og de dansere, der fulgte efter, satte flere udviklingsbølger i gang.

Ud over inspirationen fra psykoanalysen blev mange inspirerede af såvel den humanistiske psykologi som Alexander Lowens 
(1910-) bioenergitik og Wilhelm Reichs teori om kropspanseret og det ekspressive kropssprog(Lowen, 1975; Reich, 1933/1990). Den helt store fælles inspirationsåre var dog tydeligvis forbundet med Mary Wigmans lærer, Rudolf Laban (1879-1958). Labans bevægelsesanalyse blev for alvor bragt ind $\mathrm{i}$ danseterapien fra 1960'erne og gav dermed nye impulser og begreber til det arbejde, pionererne havde grundlagt ${ }^{8}$. Labans bevægelsesanalyse er også i dag et alment kerneredskab i forbindelse med både diagnosearbejde og interventionerne $\mathrm{i}$ den danseterapeutiske proces (Laban,1960). ${ }^{9}$

Efterhånden som det danseterapeutiske grundlag voksede sig stærkere, begyndte de første uddannelser at dukke op. Specielt i USA har danseterapien blandt andet gennem organisationen ADTA, ${ }^{10}$ som pionererne stiftede, udviklet sig meget fra 1960'erne og frem til i dag. Danseterapien har bredt sig til over 30 lande, og i Europa er især England og Tyskland i skrivende stund fremherskende på området. I England er der i dag uddannelser på blandt andet Roehampton University, og markante forskere sætter konstant nye dagsordener (Koch \& Panhofer, 2007). I Tyskland, hvor man har måttet leve med eftervirkningerne af, at både Rudolf Laban og en række moderne dansere flygtede under anden verdenskrig, er der i dag flere store danseterapeutiske foreninger og en række krediterede uddannelser på private institutter og universiteter (www.BTD.org). ${ }^{11}$

I Norden er danseterapien relativt ny, for manglende uddannelsesmuligheder er altid en akilleshæl i udviklingsprocessen. Danshögskolan i Stockholm udbød den første uddannelse i Norden, og i Finland har der siden 1997 været uddannelser på North Karelian University of Applied Sciences (Grønlund, 1999; Koch \& Panhofer, 2007).
I Danmark er alle danseterapeuter på forskellig vis uddannede i udlandet, men fra 2008 er der kommet uddannelsesmuligheder til København.

Selv om danseterapien - eller danse- og bevægelsesterapien (DMT = Dance Movement Therapy), som nu er den internationale betegnelse, gennem uddannelsesudviklingen har fået nye rødder, har feltet altid været præget af megen grøde og udviklingstrang. Det har været en tendens til, at hver fremtrædende personlighed udviklede sin egen metode og sine egne begreber. Denne tendens har på den ene side skabt en rig mangfoldighed og på den anden side også en vis uoverskuelighed. Faktum er dog, at der i dag både på trods af og i kraft af mangfoldige retninger eksisterer et vidt forgrenet, verdensomspændende rodnet med forskellige og dog tæt forbundne inspirationsgrundlag inden for DMT.

En af de danseterapiformer, som er tydeligst i det danske landskab for øjeblikket, er Dansergia.

\section{Dansergia - et nutidigt eksempel}

"Many of us try to dance, that is we start to move immediately without first having established a clear connection to the hara and without having thoroughly explored what music can open inside us" (Sabetti, 1991 pp. 8.).

Ovenstående citat skitserer et andet udtryk for det fysisk forankrede center, som Martha Graham introducerede i sin moderne dans. Det er det kraftfulde, kampkunstinspirerede og østligt klingende begreb hara, som er fundamentalt i danseterapiformen Dansergia (Zoetler, Persson, Stühler \& Sa- 
betti, 2001). Dansergia betyder etymologisk set dance and energy, og hara opfattes som et fysisk energicenter i midten af kroppen, som ifølge kropspsykoterapeutisk teori er forbundet med evnen til at mærke fysiske og emotionelle behov (Fusser, 2006; Sabetti, 2001). Hvor de fleste former for danseterapi er udviklede af kvindelige dansere, som søgte inspiration og kundskab fra psykologien, har Dansergia rodfæste i kropspsykoterapien og har med dette fundament udviklet sig ind i danse-terapien. Stèphano Sabetti ${ }^{12}$ har siden 1970 'erne udviklet 12 former inden for det kropspsykoterapeutiske område Life Energy Process ${ }^{13}$ (LEP) (Sabetti, 1986, 1992, 2001). ${ }^{14}$ I midten af 1980'erne opsøgte flere og flere kunstnere, musikere, performere og dansere LEP. På spørgsmålet om, hvorvidt disse principper kunne overføres til dans, begyndte Stèphano Sabetti sammen med professionelle dansere $^{15}$ at udvikle det, der senere kom til at hedde Dansergia (Zoetler et al., 2001). De første udviklingsfaser af Dansergia viste, at netop den ekspressive, kontaktfulde og kropspsykoterapeutisk forankrede bevægelse gav en unik indgang til livslyst, glæde og følelsesudtryk.

Set i nordisk perspektiv er det helt aktuelt i Danmark, at miljøet er i størst vækst - bl.a. initieret af den tidligere professionelle danser Vivian Persson (Zoetler et al., 2001). Hun er med sin unikke bevægelsesintelligens og store danseterapeutiske erfaring og viden en af dem, som også $\mathrm{i}$ internationale sammenhænge i samarbejde med Sabetti har videreudviklet Dansergia mest.

\section{Krop og psyke i den \\ multidimensionelle krop}

»Movement is only another aspect of awareness that brings personal processes into focus. Even the masters of Tai Chi and Aikido, who practise the same movements over and over, do not seek perfection in the movement but total involvement in the process until there is no separation between the art of movement and the practitioner. One becomes the Chi- or ki- the flow of life energy. This gives the martial artist tremendous strength and courage and a tremendous sense of wholeness." (Sabetti 1986, pp. 301).

Dansergia er baseret på et multidimensionelt, energibaseret kropssyn, som balance-

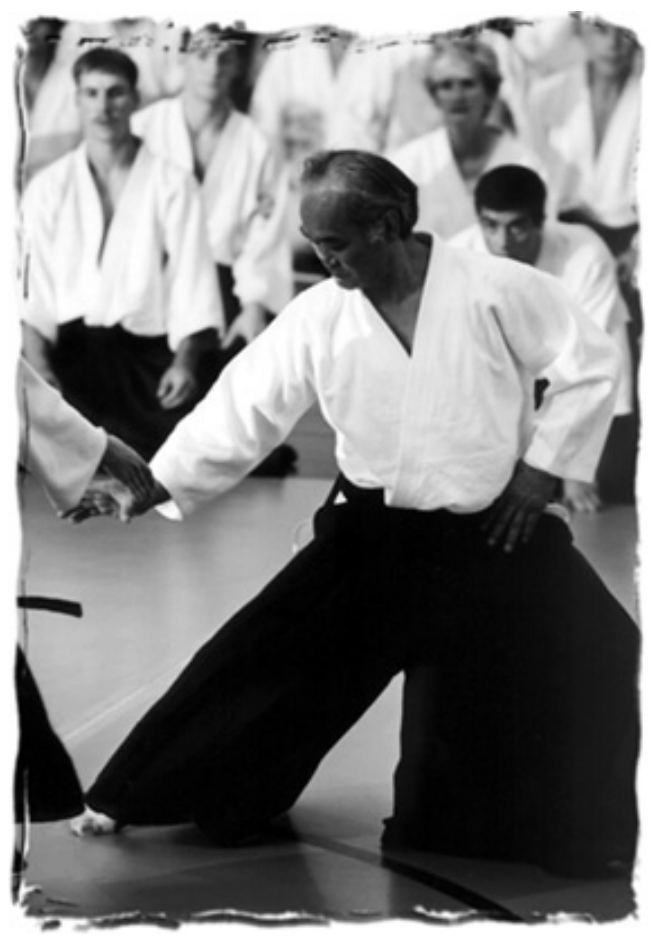

Aikidomaster. 
rer mellem vestlige krops- og psykoterapeutiske traditioner og teoretiske forankringer, østlige helbredelsesprincipper og nye forskningsresultater fra fysikkens verden. I praksis hentes der også som nævnt i citatet inspiration fra akupunktur, kampkunst og dans (Zoetler et al., 2001; Sabetti, 1986).

I Dansergia arbejdes der med udgangspunkt i begrebet livsenergi (life energy), forstået som en grundlæggende dynamisk og fundamental livskraft (Zoetler et al., 2001; Sabetti, 1986). Energibegrebet, som har både østlige og vestlige inspirationskilder, forstås som i fysikkens verden dybest set som bevægelsesbølger med forskelligartede vibrationer, frekvenser og amplituder, der i kroppen kommer til udtryk i f.eks. åndedræt, stemme og den enkeltes kulturelt og samfundsmæssigt prægede, men også unikke kropssprog, fysiske holdning og karakteristiske bevægelser (Sabetti, 1986).

Kroppens udtryk og struktur er ifølge Sabetti (2001) forbundet med følelser, som også udtrykkes som bevægelser. Det enkelte menneske forsøger ofte at beskytte sig eller undertrykke psykologiske temaer. Derfor søger kroppen ofte at skabe et kompromis gennem bevægelse, kropssprog eller fysisk holdning.

"In order to survive the individual have learnt to express themselves as best they can; but the movements they produce sometimes seem painful and/or frightened, expressing only parts of the whole " (Zoetler et al., 2001, pp. 63).

Kroppens rytme og energi kan for de fleste mennesker i perioder opleves som værende ude af balance, og i mere alvorlige tilfælde kan rytmen være brudt. Når det organiske energiflow er ubalanceret, kan kroppen forekomme stiv, oppustet, leddeløs, opgi- vende eller forladt. Fysisk, psykisk og emotionel energi er ud fra dette perspektiv ofte også helt konkret og synligt bundet i f.eks. musklerne og er dermed ikke tilgængelig for ekspressivitet eller følelser som frihed, spontanitet og lyst.

I Dansergia arbejdes der altså med et multidimensionelt syn på den menneskelige krop, og fokus bliver således i både teori og praksis at skabe bevidsthed om sammenhængen - ikke kun mellem krop og psyke, men mellem fysiske, mentale, psykologiske, emotionelle, sociale, kulturelle og spirituelle bevægelsesniveauer. Hvor Isadora Duncan talte om fri bevægelse og Mary Whitehouse om autentisk bevægelse, arbejdes der i Dansergia med essentielle bevægelser, der indeholder intense forandringspotentialer og opstår, når gamle, grundlæggende handle- og bevægelsesmønstre (energy patterns) forandres, og der opstår et øget flow i kroppen, samtidigt med at forskellige bevægelsesniveauer smelter sammen (Zoetler et al., 2001; Sabetti, 2001). Michaels proces, som indledte denne artikel, er et eksempel på, hvordan han for at genfinde gnisten må forandre det på den ene side opgivende og på den anden side kontrollerede bevægelsesmønster, som blandt andet er synligt i ryggens rigiditet. Selv om Michael »holder sig selv oppe« og er bange for at »gå ned «' er det paradoksalt nok ved at søge ned i kroppen og mærke det også følelsesmæssige kaos, at han har mulighed for at genfinde livslysten.

Selv om der overordnet set er stor samklang mellem Dansergia og andre danseterapeutiske tilgange, vil Dansergia kunne få frugtbar inspiration og styrke et fællesskabende sprog ved i højere grad også at indarbejde Labans bevægelsesanalyse i de energetiske begreber. På grund af den stærke kropspsykoterapeutiske forankring bidra- 
ger Dansergia dog også med et forøget fokus på det multidimensionelle, energetiske perspektiv. Derudover kan danseterapiformen via indflydelsen fra kampkunstens verden siges at byde ind med en tydeligere maskulin kvalitet i det gennem flere generationer primært kvindedominerede danseterapeutiske landskab.

Udviklingen af den forskningsmæssigt funderede indsigt i kroppens og bevægelsens terapeutiske potentiale kan på sigt udvikles yderligere. Her handler udfordringen inden for det danseterapeutiske felt nu om at stå sammen og i fællesskab markere en brydningstid, der også på det forskningsorienterede område overvinder det dualistiske blik på krop og psyke. De danse- og også kropspsykoterapeutiske tonede forskningsprojekter har på mange måder levet i skyggen af de kognitive tilgange til terapi og psykologi. Nu er det på tide at træde frem i lyset ved i langt højere grad at skrive kroppen og dermed det helhedsorienterede blik ind i psykologien.

Netop nu er en sådan proces i gang.

\section{Postmoderne forskningsmoessige tendenser}

\section{Antologien Advances in Dance Movement} Therapy, som indeholder forskningsbidrag fra fem kontinenter, er med til at markere en ny æra og viser, at også forskningen er i hastig udvikling inden for DMT. I denne antologi sætter redaktøren Sabine Koch (2006) det danse- og bevægelsesterapeutiske arbejde ind i en aktuel og multifacetteret 'embodiment' kontekst. Embodimentbegrebet har rod i en fænomenologisk kropsforståelse, og Koch argumenterer for, at DMT er et praktisk forankret eksempel på, hvordan der kan arbejdes med embodiment ud fra et helhedsorienteret synspunkt, der ud over body-mind også arbejder med sociale og kulturelle dimensioner af kropsligheden (Ibid.; Merleau -Ponty 1962).

Sabine Koch er sammen med Helen Payne (Payne, 2007) en af de mest fremtrædende europæiske forskere inden for området $\mathrm{i}$ dag, og med sit bidrag sætter hun dermed danse- og bevægelsesterapien ind $i$ en generel og dermed også nødvendig brobyggende kropsteoretisk kontekst i relation til de fremtrædende sprogdiskurser inden for både den almene psykologi og den internationale kropskulturforskning.

Det forsknings- og formidlingsorienterede arbejde må altså i dag balancere mellem på den ene side at finde et sprog, der kan få de etablerede systemer i tale og på den anden side fortsat være frontløber og markere en avant-garde bevægelse $i$ forhold til det helhedsorienterede kropssyn. I forhold til de postmoderne tendenser tager forfatteren Daria Halprin (2003) et skridt videre end Koch. Ifølge Halprin er vi filosofisk set ved at skabe nye paradigmer inden for psykologi, filosofi, kunst, uddannelse, medicin og videnskab. Paradigmerne bevæger sig hen $\mathrm{i}$ mod en helhedsorienteret kropsforståelse, som på mange måder forbinder et nyt grundlag med fortiden, hvilket tydeligt kommer frem i nedenstående citat.

»The new paradigms of the twentieth and twenty-first centuries attempt to reframe our understanding of the complexities of life in the post-modern age - including the necessity to move with chaos and diversity, the certain birth of new order, and the constant movement of consciousness in all things. We are returning to the principles and laws by which people and communities lived in the most ancient times. Yet we are making this full circle in 
new ways on new ground, with new and more complex challenges. In the fields of psychology, philosophy, art, education, medicine, and science these new paradigms are pointing us toward a more embodied life, one in which art, science, psychology and spirituality are no longer divorced or kept separate but rather are reconnected through shared metaphors and universal principles and ideas" (Halprin, 2003, pp. 77).

Den helhedsforståelse, som Halprin foreslår, overskrider grænserne mellem tidligere etablerede strukturer og er en udfordring for traditionelle forståelsesrammer. Hvis psykologi, fysik, kunst, videnskab og spiritualitet ikke længere er adskilt af vandtætte skodder, vil der på trods af forskellige indfaldsvinkler kunne udvikle sig nye paradigmer $\mathrm{i}$ forhold til en dybere forståelse af kropsligheden.

Det er en forståelse, der også på sigt vil kunne få konsekvenser for praksis.

\section{Nye spor - ad kendte og ukendte veje}

Udviklingen inden for DMT flyder ad langt mere uransagelige veje, end det har været muligt at afdække her. Det, som for et øjeblik siden var nu, er allerede historie, og det sidste kapitel i denne fortælling er kun nogle få timer gammelt. En email poppede op: »DMT in Europe«. Det er en rapport fra et europæisk netværk, der fortæller om danseog bevægelsesterapeutisk arbejde, uddannelsesmuligheder og forskningstiltag i 19 lande; en rapport, som også indgår i et globalt netværk (Koch \& Panhofer, 2007).
Denne rapport dokumenterer, hvordan arbejdet med fokus på sammenhængen mellem krop og eksistens er brugbart for mange, også marginaliserede grupper, for hvem sproget har mistet sin relevans.

De forholdsvis få udviklingsspor, artiklen har kunnet afbillede, vidner om, at det helhedsorienterede arbejde med krop og bevægelse synes at indeholde en stærk livskraft. Selv om frøene er lagt i tidernes morgen, kan denne livskraft også i nutidens identitetsudfordrende samfund vise sig at have stor aktualitet - ikke mindst i kraft af den stigende individualisering, refleksivitet og eksistentielle utryghed på den ene side og den tilsyneladende omsiggribende frihed på den anden. Derfor kan der være grund til fortsat, sammen med de teoretiske overvejelser over sammenhængen mellem krop, psyke og samfund, at være med til at udvikle det eksisterende internationale rodnet og dermed synliggøre de både praktisk udviklede og forskningsmæssigt forankrede potentialer $\mathrm{i}$ at arbejde med kroppens sprog og bevægelsens psykologi via DMT.

Kroppens sprog er uanset tidsperiode og kulturelt tilhørsforhold det lille barns primære sprog og udgør måske også i det enkelte menneskes personlige og sociale udviklingsprocesser et potent råstof. Derfor kan danseterapeutisk indsigt også skabe grobund for udviklingen af en bevægelsespsykologi, der kan bruges $i$ et bredt idrætsligt og sundhedsmæssigt perspektiv til inspiration for mangfoldige professionsområder og praksissammenhænge. Disse potentialer vil i fremtiden udvikle sig ad endnu ukendte veje - og måske er det på tide, at vi i Danmark begynder at åbne øjnene, så også vi kan være med til at sætte nye spor. 


\section{Noter}

1 Artiklen er aktuel, da der i Danmark i 2007 er blevet dannet en danseterapeutisk forening. Danseterapeuter.dk - Danish Dance Movement Therapy Association er del af et internationalt europæisk samarbejde.

2 Navnet Dansergia er beskyttet med trademark ${ }^{\circledR}$. Brugen af begrebet i denne artikel betyder ikke, at denne beskyttelse er ophævet.

3 Når der ofte henvises til flere referencer ad gangen, er det fordi, der er overensstemmelse eller kun supplerende nuanceforskelle mellem disse.

4 Den mest brugte internationalt anerkendte definition på danseterapi er beskrevet af American Dance Therapy Association: "Dance/Movement Therapy is the psychotherapeutic use of movement as a process which furthers the emotional, social, cognitive, and physical integration of the individual.« (www.ADTA.org., 2008).

5 Marian Chase, (1896-1970), Blance Evan (ca. 1909-1982), Mary Whitehouse (1911-1979), Trudi Schoop (1903-1998), Alma Hawkins (1904-1998) og norskfødte Liljan Espenak (1905-1988) udviklede et bredt fundament af kliniske metoder, som kan spores i danseterapien den dag i dag (Levy, 1988; Trautmann-Voigt, 2006).

6 Marian Chace, og Mary Whitehouse grundlagde desuden sammen American Dance Therapy Association. Marian Chace var formand for stiftelsen fra 1966 (www.adta.org).

7 Hendes papers og noter er samlet, redigeret og udgivet posthumt af en af hendes elever Harris Chaiklin i 1975.

8 Fysioterapeuten Irmgard Bartenieff spillede en vigtig rolle $\mathrm{i}$ forhold til at implementere Labans arbejde i danseterapien. Hun udgav også selv senere en del skriftligt materiale, herunder bogen Body, movement: Coping with the environment. (New York, 1980).

9 Laban, som lod sig inspirere af fysik, filosofi, psykologi og kunst, søgte ikke at finde teknikker, men fundamentale principper for den menneske- lige bevægelse. Hans store skriftlige produktion, som rummer hans bevægelseslære/ bevægelsesanalyse (movement analysis), undersøger blandt andet bevægelsens følelsesmæssige ekspressive tone (effort) beskrevet ud fra begreberne tid, kraft, rum og flow.

10 (American Dance Therapy Association).

11 Paradoksalt nok var også krigsveteraner og overlevende soldater efter anden verdenskrig i Tyskland og USA med til at skabe grobund for danseterapien. Psykoanalysens primære fokusering på barndommen var nemlig ikke til stor hjælp for behandlingen af krigsneuroser, hvorimod man langsomt begyndte at indse, at de ekspressive kunstformer som musik, kunst og dans havde en helende effekt (Grønlund, 1999).

12 Stèphano Sabetti er bl.a selv uddannet hos Alexander Lowen (1910-), John Pierrakkos (19212001) og gestaltterapiens stamfar Fritz Perls (1893-1970).

13 Navnet Life Energy Process er beskyttet med trademark ${ }^{\circledR}$. Brugen af begrebet i denne artikel betyder ikke, at denne beskyttelse er ophævet.

14 De 12 former, som er akkrediterede af EABP (European Association for Body Psychotherapy), består ud over Dansergia af de ekspressive former: Artra - kunstterapi, Voicia - stemmeterapi, Musica - musikterapi og Teatro Energetico, dramaterapi. Hertil kommer LET- en spirituelt orienteret kropspsykoterapi, Sphurana Yoga - kropspsykoterapi med inspiration fra bl.a.Hatha yoga, Acquasus - ekspressiv og klinisk kropspsykoterapi i vand og Shinkido- en massageterapiform. Derudover findes de udviklingsorienterede former Organetics - organisationsudvikling, Process Inquir $y$ - energibaseret coaching, kommunikation og udvikling gennem samtale og Energy Pedagogy - en energibaseret og oplevelsesorienteret læringsform (Sabetti \& Freligh, 2001).

15 Danserne Pleiada Zoetler og Renate Köckeis. 


\section{Litteratur}

Boadella D. Soma-Semantik-Bedeutungen des Körpers. In: Marlock G. \& Weiss H. (red.) Handbuch der Körperpsychotherapie. pp. 208-216 (Stuttgart/New York, 2006).

Chaiklin, S. Marian Chace. Her Papers (Columbia, 1974).

Csordas, T. Embodiment and cultural Phenomenology. In G. Weiss \& H. F. Haber (red.)

Perspectives on Embodiment. pp 143-165 (New York, 1999).

Chodorow J. Dance Therapy and Depth Psychology (New York, 1991).

Duncan I. My life (New York, 1927).

Fusser M. Die Atembewegung. In: Marlock G. \& Weiss H. (red.). Handbuch der Körperpsychotherapie. pp. 646-658 (Stuttgart/New York, 2006).

Graham M. Blood Memory: An Autobiography (NYC, 1991).

Grønlund E. Konstnärliga terapier. Bild, dans och musik $i$ den läkande processen (Stockholm 1999).

Halprin D. The expressive body in life, art and thera$p y$ (London \& Philadelphia, 2003).

Houmark P. Mary Whitehouse og autentiske bevagelser I: Hansen J. og Trangbæk E. (red.) Mellem terapi og bevægelse - Idrætshistoriernes veje. pp.67-82 (Odense, 1994).

Huizinga J. Homo ludens. Om kulturens oprindelse $i$ leg (København, 1993).

Koch S. \& Bräuninger I. (red.) Advances in Dancel Movement Therapy (Berlin, 2006).

Koch S. Interdisciplinary embodiment approaches. Implications for creative arts therapies I: Koch S. \& Bräuninger I. (red.) Advances in Dance/Movement Therapy (Berlin, 2006).

Koch S. \& Panhofer H. DMT in Europe. Reports for the Tallinn Meeting of the European Network for the Developement of Dance Movement Therapy (Heidelberg, 2007. Upubliceret).

Køppe, S. Kroppens historie I: S. Køppe et al. Kroppen i psyken (København, 2004).

Laban, R. The Mastery of Movement (London, 1960).

Levy F. Dance movement therapy. A healing art (Reston, 1988).

Lowen, A. Bioenergetics (New York, 1975).
Manning S. A. Ecstasy and the Demon. Feminism and Nationalism in the Dances of Mary Wigman (Berkerly \& Los Angeles 1993).

Merleau-Ponty M. Phenomenology of perception (London, 1962/2004).

Merloo J. The Dance (New York, 1960).

Payne H. Tracking the web of interconnectivity. In: Body Movement and Dance in Psychotherapy, 1.1. pp. 7-17 (Oxton, 2007).

Reich W. Character Analysis (New York, 1945/1993).

Sabetti S. Wholeness principle (Sherman Oaks, 1986).

Sabetti S. Expressive energy (München, 1991).

Sabetti S. Dansergia (Sherman Oaks, 1992).

Sabetti S. \& Freligh L. Life energy process, forms dynamics - principles (München, 2001).

Sorell W. Mary Wigman. Ein Vermächtnis (Wilhelmshaven, 1986).

Sparkes A. Telling tales in sport and physical activity. A qualitative journey (Leeds, 2002).

Trautman-Voigt S. Tanztherapie I: Marlock G. \& Weiss H. (red.) Handbuch der Körperpsychotherapie. pp.885-887 (Stuttgart/New York, 2006).

Whitehouse M. Physical movement and personality. Paper presented at the meeting of the Analytical Psychology Club (Los Angeles, 1963).

Whitehouse M. Jung and dance therapy: Two major principles I: Bernstein P. L. (red.) Eight theoretical approaches in dance movement therapy (Iowa, 1979).

Wigman M. Die Sprache des Tanzes (Stuttgart, 1967).

Winther H. Et portrcet af Mary Wigman - de mørke krcefters danserinde I: Hansen J. \& Trangbæk E. (red.) Mellem terapi og bevægelse - Idrætshistoriernes veje. pp. 49-66 (Odense, 1994).

Winther H. From crocodile to woman. The multidimensionality and energy dynamics of movement seen in the light of the dance therapy form Dansergia In: Koch S. \& Bräuninger I. (red.) Advances in Dance/Movement Therapy. pp.154-166 (Berlin, 2006).

www.BTD.org. 1.februar 2008

www.ADTA.org.1.februar 2008

Zoetler P., Persson V., Stühler V. \& Sabetti S. Dansergia In: Sabetti S. \& Freligh L. (red.) Life energy process, forms - dynamics - principles. pp.5575 (München, 2001). 